\title{
8
}
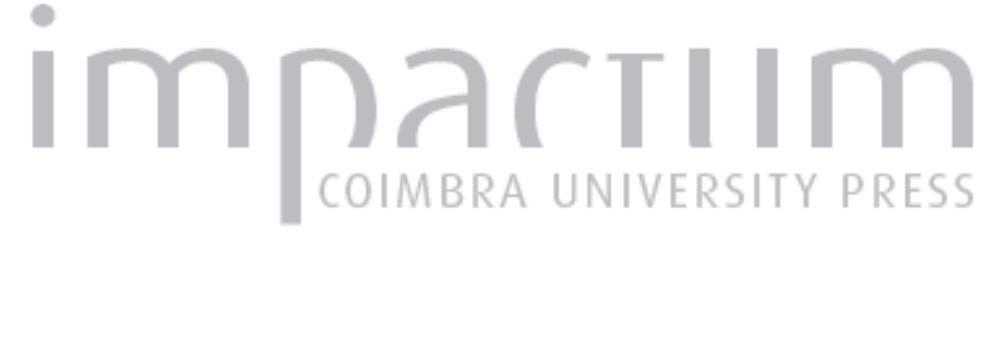

\section{Ninguém ouve quando todos falam: sobre o futuro dos meios de comunicação social na vida mediática}

Autor(es): Deuze, Mark

Publicado por: Imprensa da Universidade de Coimbra

URL persistente:

URI:http://hdl.handle.net/10316.2/43149

DOI:

DOI:https://doi.org/10.14195/2183-6019_4_1

Accessed : $\quad$ 26-Apr-2023 13:06:41

A navegação consulta e descarregamento dos títulos inseridos nas Bibliotecas Digitais UC Digitalis, UC Pombalina e UC Impactum, pressupõem a aceitação plena e sem reservas dos Termos e Condições de Uso destas Bibliotecas Digitais, disponíveis em https://digitalis.uc.pt/pt-pt/termos.

Conforme exposto nos referidos Termos e Condições de Uso, o descarregamento de títulos de acesso restrito requer uma licença válida de autorização devendo o utilizador aceder ao(s) documento(s) a partir de um endereço de IP da instituição detentora da supramencionada licença.

Ao utilizador é apenas permitido o descarregamento para uso pessoal, pelo que o emprego do(s) título(s) descarregado(s) para outro fim, designadamente comercial, carece de autorização do respetivo autor ou editor da obra.

Na medida em que todas as obras da UC Digitalis se encontram protegidas pelo Código do Direito de Autor e Direitos Conexos e demais legislação aplicável, toda a cópia, parcial ou total, deste documento, nos casos em que é legalmente admitida, deverá conter ou fazer-se acompanhar por este aviso.

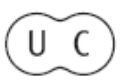


revista de comunicação,

jornalismo e espaço público

$\angle$

Periodicidade

Semestral

Imprensa da Universidade de Coimbra Coimbra University Press

\section{mediapolis}

comunicação e transformações sociais

communication and social transformations 



\section{Ninguém ouve quando todos falam: sobre o futuro dos meios de comunicação social na vida mediática}

No one listens when everyone speaks: on the future of media in media life

\section{Resumo}

O futuro da comunicação social enquanto indústria e em termos dos profissionais a que dá emprego é analisado utilizando a teoria da comunicação social e a perspetiva da produção relativamente à comunicação social enquanto trabalho. Dada a dependência da sociedade nos meios de comunicação para contar as suas histórias, e o facto de as vidas quotidianas das pessoas serem representadas nesses mesmos meios de comunicação, o momento em que estes mundos colidem constitui um ponto de partida excelente para uma exploração futurística. Utilizando uma taxonomia dos meios de comunicação social como artefactos, atividades e organizações sociais, o trabalho mediático é analisado do ponto de vista de uma oportunidade estética, de uma chamada ética à ação e de uma responsabilidade social.

Palavras-chave: Teoria dos media, trabalho mediático, consumo mediático, novos media.

\section{Abstract}

The future of media as an industry and in terms of the professionals it employs is considered using media theory and the production perspective on media as work. Given society's reliance on media to tell its stories, and people's everyday lives playing out within those same media, the moment these worlds collide provides an excellent starting point for futuristic exploration. Using a taxonomy of media as artefacts, activities and social arrangements, media work is considered in terms of an aesthetic opportunity, an ethical call to action, and a social responsibility.

Key words: Media theory, media work, media consumption, new media. 


\section{Vida mediática}

Os meios de comunicação estão para nós como a água está para os peixes. Isto não significa que a vida seja determinada pelos meios de comunicação - sugere apenas que, quer gostemos quer não, todos os aspetos das nossas vidas ocorrem nos meios de comunicação. Vivemos nos meios de comunicação, não com os meios de comunicação (Deuze, 2012).

Não é de admirar que os meios de comunicação se tenham tornado fulcrais para a nossa compreensão do mundo e o nosso papel no mesmo. Os meios de comunicação são muito mais do que as empresas que para eles produzem conteúdos, do que as tecnologias que usamos e do que a forma como os meios de comunicação se encaixam nas nossas vidas quotidianas. $\mathrm{Na}$ nossa forma de vivermos nos meios de comunicação, em grande medida irrefletida, não há nada exterior aos meios de comunicação. Somos atraídos para os meios de comunicação naquilo a que consideraria um processo através do qual o mundo mediático e o mundo sistemático convergiram no mundo da vida (Deuze, 2014). Nesse sentido, é complicado fazer-se uma verdadeira reflexão sobre o papel dos meios de comunicação na nossa vida, na medida em que o mundo da vida é o mundo que experimentamos de forma mais direta, instantânea e sem reservas.

Parte da vida mediática implica aceitar uma supersaturação de mensagens dos meios de comunicação e de máquinas nos lares, locais de trabalho, centros comerciais, bares e restaurantes e em todos os outros lugares intermédios do mundo atual. A investigação realizada em países de todos os continentes mostra consistentemente de que forma, ao longo dos anos, cada vez mais do nosso tempo é passado a usar meios de comunicação e como o facto de estarmos a ser simultaneamente expostos a vários meios de comunicação se tornou uma característica habitual da vida quotidiana. O consumo dos meios de comunicação ocorre regularmente a par da produção dos mesmos, à medida que as distinções relevantes entre atividades mediáticas como fazer zapping, zipping, visualizar, ler e transferir e ações como conversar num chat, reencaminhar, remisturar, editar e carregar desaparecem da consciência ativa das pessoas quando usam os meios de comunicação.
A convergência do hardware e software mediático, de comportamentos $\mathrm{e}$ expetativas mediáticas e a constante omnipresença dos meios de comunicação na vida quotidiana colocam desafios tremendos à investigação dos meios de comunicação e da comunicação em geral, bem como ao estudo das profissões mediáticas, como o jornalismo, em particular. Como poderemos verdadeiramente comunicar num contexto digital em que todos falam e (portanto) ninguém ouve? Como poderemos falar seriamente de efeitos mediáticos ou de leituras preferenciais de mensagens mediáticas no contexto de uma multiplicidade mediática, em que as pessoas são simultaneamente expostas a uma enxurrada de diretivas e despachos criados por amigos, familiares, colegas, marcas e empresas, bem como por governos e inúmeras burocracias? Numa altura em que as pessoas enviam mais do que recebem, em que filtrar, ponderar e eliminar comunicações se afigura essencial para sobreviver à superabundância informativa, o que significa ser-se um contador de histórias (profissional)? Além disso, como poderão os meios de comunicação e os estudos de comunicação abordar devidamente questões tão complexas? 


\section{Media Life}

Media are to us as water is to fish. This does not mean life is determined by media - it just suggests that whether we like it or not, every aspect of our lives takes place in media. We live in media, not with media (Deuze, 2012).

It is no surprise media have become central to our understanding of the world and our role in it. Media are so much more than the companies that produce content for it, the technologies we use, and the way media fit into our everyday lives. In our largely unreflective way of living in media, there is no outside to media. We are drawn into media in what I consider a process where the media world and the system world have collapsed into the lifeworld (Deuze, 2014). In that sense, effective reflection on the role of media in our life is complicated because the lifeworld is the world we experience most directly, instantly, and without reservation.

Part of media life means coming to terms with a supersaturation of media messages and machines in households, workplaces, shopping malls, bars and restaurants, and all the other in-between spaces of today's world. Research in countries across all continents consistently shows how through the years more of our time gets spent using media, and how being concurrently exposed to media has become a regular feature of everyday life. Consuming media regularly takes place alongside producing media, as meaningful distinction between media activities such as zapping, zipping, viewing, reading, and downloading and actions like chatting, forwarding, remixing, editing, and uploading disappears from people's active awareness of media use.

The convergence of media hardware and software, of media behaviors and expectations, and the pervasiveness of unbiquitousness of media in everyday life pose tremendous challenges to researching media and communication in general, and the study of media professions such as journalism in particular. How can one effectively communicate in a digital context where everyone is talking and (therefore) no one is listening? How can one meaningfully speak of media effects or preferred readings of media messages in the context of a media manifold, where people are concurrently exposed to a deluge of directives and dispatches generated by friends, family members, colleagues, brands and companies, as well as governments and numerous bureaucracies? In a time where people send more than that they receive, when sifting, weighing and deleting communications seems to be key to survive information overabundance, what does it mean to be a (professional) storyteller? Furthermore, how can media and communication scholarship adequately address such complex questions? 


\section{Conceitos emergentes: mediapolis, mediaspace, polymedia, mediatização}

Nos últimos anos, foram várias as tentativas no sentido de integrar teoricamente a complicada natureza em rede e cada vez mais integrada do nosso ambiente mediático. As nossas vidas nos meios de comunicação ocorrem naquilo a que Roger Silverstone (2006) designou uma mediapolis: um espaço público largamente mediado onde os meios de comunicação sustentam e abrangem as experiências e expressões da vida quotidiana. "A mediapolis [...] assinala a presença na vida quotidiana, tanto do ponto de vista empírico como potencial, desse espaço mediado no qual, enquanto participantes, confrontamos o mundo, e onde, enquanto cidadãos, nos podemos confrontar uns aos outros" (111). Neste espaço, os meios de comunicação ficaram infinitamente interligados a todas as formas de ser, ver, mover e agir - sem substituírem o mundo da experiência vivida. Ampliando esta noção de espacialidade na vida mediática, Nick Couldry e
Anna McCarthy veem uma cocriação gradual de um mediaspace, "incluindo tanto o tipo de espaços criados pelos meios de comunicação, como os efeitos que as organizações espaciais existentes têm nas formas mediáticas à medida que estas se materializam na vida quotidiana" (2004: 1-2). O controlo (ou ilusão do mesmo) permitido por um mediaspace torna-o distinto de outros espaços da vida - por exemplo, os de casa e do trabalho - ao mesmo tempo que explica a sua colonização gradual de outras esferas da existência humana.

A influência de um estilo de vida mediado na nossa rotina diária é evidente em estudos antropológicos realizados com várias comunidades (tais como migrantes, trabalhadores de escritório e estudantes) por Mirca Madianou e Daniel Miller, que propõem que as pessoas de todo o mundo, oriundas de diversos contextos sociais e económicos, vivem cada vez mais numa situação de polymedia: estão expostas a uma pluralidade de meios de comunicação que alteram as relações entre a tecnologia da comunicação e a sociedade pelo simples facto da estarem omnipresentes e aparentemente plenamente integradas no domínio social e emocional da existência quotidiana das pessoas (Madianou e Miller, 2013). Vários académicos propuseram uma teoria abrangente da mediatização no sentido de representar o processo dinâmico através do qual a sociedade, os meios de comunicação e a vida quotidiana convergem. Segundo o trabalho inovador de Stig Hjarvard, "a mediatização refere-se, regra geral, ao processo através do qual elementos essenciais de uma atividade social ou cultural (p. ex., política, religião e educação) são influenciados pelos meios de comunicação e se tornam dependentes dos mesmos" (2012: 30). Andreas Hepp considera a mediatização um conceito que pode ser usado "para analisar a inter-relação (de longo prazo) entre as mudanças mediáticas e de comunicação e as mudanças socioculturais de uma forma crítica" (2013: 6).

Aqui, é essencial não fazermos distinções entre o que as pessoas fazem e o que os meios de comunicação fazem - nem entre o que acontece às sociedades em geral e aos indivíduos em particular - mas antes 


\section{Emerging Concepts: Mediapolis, Mediaspace, Polymedia, Mediatization}

In recent years, several attempts have been made to theoretically integrate the complicated networked and increasingly integrated nature of our media environment. Our lives in media take place in what Roger Silverstone (2006) labels a mediapolis: a comprehensively mediated public space where media underpin and overarch the experiences and expressions of everyday life. "The mediapolis [...] signals the presence in everyday life, both empirically and potentially, of that mediated space within which as participants we confront the world, and where, as citizens, we might confront each other" (111). In this space media have become infinitely intertwined with every single way of being, seeing, moving, and acting - without replacing the world of lived experience. Extending this notion of spatiality within media life, Nick Couldry and Anna McCarthy see a gradual co-creation of a mediaspace, "encompassing both the kind of spaces created by media, and the effects that existing spatial arrangements have on media forms as they materialize in everyday life" (2004: 1-2). The (illusion of) control that a mediaspace affords makes it distinct from other spaces in life for example those of the home and work - while at the same time explaining its gradual colonization of other spheres of human existence.

How far and wide a mediated lifestyle plays out in our everydayness is evident in anthropological work with various communities (such as migrants, office workers, and students) of Mirca Madianou and Daniel Miller, who propose that people around the world, coming from a wide variety of social and economical backgrounds, increasingly live in a situation of polymedia: exposed to a plurality of media which change the relationships between communication technology and society by the mere fact of their omnipresence and seemingly effortless integration into the social and emotional realm of people's everyday existence (Madianou and Miller, 2013). Several scholars have proposed a comprehensive theory of mediatization to capture the dynamic process of society, media, and everyday life converging. According to pioneering work by Stig Hjarvard, "mediatization generally refers to the process through which core elements of a social or cultural activity (e.g., politics, religion, and education) become influenced by and dependent on the media" (2012: 30). Andreas Hepp considers mediatization as a concept that can be used "to analyse the (longterm) interrelation between media-communicative and socio-cultural change in a critical manner" (2013: 6).

The key here would be not to draw distinctions between what people do and what media do - not between what happens to societies in general and to individuals in particular, but to focus on what the qualities of living in media are and thusly how technological and social change look like in media. What happens in a media life remixes the permanence of the sheer limitless recording and storage of every single aspect of our lives that the digital age affords with the relative impermanence of continuously 
concentrarmo-nos em saber quais são as qualidades da vida nos meios de comunicação e, desta forma, como a mudança tecnológica e social transparecem nos meios de comunicação. $\mathrm{O}$ que acontece numa vida mediática conjuga a permanência da mera gravação e conservação ilimitada de cada aspeto das nossas vidas, permitidas pela era digital, com a relativa impermanência da transmissão contínua de toda essa informação pormenorizada ao mundo e da criação dos nossos próprios mundos nos meios de comunicação (através de uma customização, personalização e filtragem intermináveis de interfaces e informações). A autocomunicação de massas (Castells, 2007: 246ff) é composta por atividades mediadas de automonitorização, autocriação de imagem de marca e interação eu-outro, recorrendo simultaneamente a um conjunto de tecnologias, plataformas e serviços que mudam de forma dinâmica. Os meios de comunicação que usamos para estas práticas estruturam tecnicamente a forma como as nossas atividades são registadas e armazenadas, determinam intangivelmente a forma como nós (e outros) acedemos aos dados e incluem possibilidades para redigir, editar e rever informações sobre nós próprios e os outros. Neste processo, os meios de comunicação aumentam e ampliam subtilmente a vida à medida que os brandimos em interfaces de utilizador cada vez mais naturais (como sejam os ecrãs táteis e os sensores de movimento). Os meios de comunicação desaparecem, apenas para reaparecerem como atmosferas, estados de espírito, capacidades e personalidades. Em síntese: as pessoas preocupam-se efetivamente com os seus meios de comunicação, e essa relação cada vez mais íntima vai muito além de uma 'síndrome do brinquedo novo' em que se quer o telemóvel ou sistema operativo da próxima geração.

\section{A vida mediática \\ e a indústria}

A questão é: o que podem os profissionais dos meios de comunicação e as indústrias que deles dependem fazer num mundo onde todos falam e ninguém ouve? Os contadores de histórias profissionais nos meios de comunicação (ou seja, jornalistas, criativos de publicidade, comunicadores de marketing, argumentistas de cinema e televisão, realizadores, atores e atrizes, criadores de jogos, músicos; ver Deuze, 2007) enfrentam desafios semelhantes neste contexto. Os canais e serviços mediáticos estão a integrar-se e a espalhar-se por inúmeras plataformas (como telemóveis, computadores, online e independentes), públicos cada vez mais informados sobre os meios de comunicação questionam, criticam ou simplesmente optam por não ver anúncios (destruindo o modelo de negócios dominante na indústria), demasiados modelos de distribuição lutam para criar audiências e os consumidores de meios de comunicação são cada vez mais recrutados como colegas na conceptualização, criação, curadoria e circulação de conteúdos - um processo 
communicating all that detailed information to the world and creating our own worlds within media (through endless customization, personalization, and filtering of interfaces and information). Mass self-communication (Castells, 2007: 246ff) consists of mediated self-monitoring, self-branding and self-other interaction, concurrently using a dynamically changing ensemble of technologies, platforms, and services. The media we use for these practices technically structure the way our activities are recorded and stored, softly determine how we (and others) access the data, and include affordances to redact, edit and revise information about ourselves and others. In the process, media subtly augment and extend life as we wield them through increasingly natural user interfaces (such as touchscreens and motion sensors). Media disappear, only to re-appear as atmospheres, moods, abilities and personalities. In short: people really care about their media, and that increasingly intimate relationship goes well beyond a 'shiny toy syndrome' of wanting the next generation mobile phone or operating system.
In a time where people send more than that they receive, when sifting, weighing and deleting communications

seems to be

key to survive information

overabundance, what does it

mean to be a (professional) storyteller?

\section{Media Life \\ and the Industry}

The question is, what can media practitioners and the industries that rely on them do in a world where everyone is talking and no one listens? Professional storytellers in the media (i.e. journalists, advertising creatives, marketing communicators, film and television writers, directors, actors and actresses, game developers, music artists; see Deuze, 2007) face similar challenges in this context. Media channels and services are integrating and spreading across a variety of platforms (such as mobile, desktop, online, and standalone), increasingly media literate publics question, critique or all-together opt out of advertisements (undercutting the dominant business model throughout the industry), one-to-many distribution models are struggling to generate audiences, and media consumers are increasingly enlisted as colleagues in conceptualizing, creating, curating and circulating content - a gradual process Henry Jenkins (2006) defines as convergence culture. 
gradual que Henry Jenkins (2006) define como cultura de convergência.

Nas suas tentativas (frequentemente fúteis) de domesticar a fera indisciplinada da cultura mediática contemporânea, a indústria mediática consolidou-se ao longo das últimas décadas, com investidores globais, holdings e grandes multinacionais a devorar empresas, estúdios e editoras a um ritmo acelerado, rapidamente seguidas por regimes de gestão que visam normalizar e racionalizar práticas nas respetivas redes. $\mathrm{O}$ pressuposto subjacente a tudo isto foi o de que, ao integrar e fazer convergir elementos anteriormente separados da indústria mediática designadamente, a produção e o marketing, o desenvolvimento de públicos e a estratégia de conteúdos, o negócio e a criatividade -, a natureza tradicionalmente insular e frequentemente idiossincrática do trabalho mediático se tornaria mais flexível, centrada no consumidor, e seria capaz de se mover com o mercado entre e através de várias plataformas e canais mediáticos.

O paradoxo destes desenvolvimentos reside no facto de que, na vida mediática, os profissionais dos meios de comunicação deveriam estar a ter uma grande oportunidade com o seu trabalho, na medida em que as pessoas estão claramente envolvidas emocionalmente com todos os seus meios de comunicação e de que os dados digitais multiplataforma criados na vida mediática prometem direcionar mensagens habilmente preparadas para públicos ávidos. Contudo, é o oposto que se afigura verdadeiro: as pessoas parecem mais felizes a passar tempo nos seus próprios meios de comunicação, ou seja, nas redes sociais online (como o Facebook ou o WeChat), e as perspetivas para o trabalho na indústria estão a tornar-se profundamente precárias, forçando os profissionais mediáticos a serem 'empresariais' (Cohen, 2015), o que, na maioria das vezes, se refere, de forma eufemística, a condições de trabalho que podem ser entendidas, na melhor das hipóteses, como exploratórias e incertas.

É seguro dizer que estes são tempos complexos para a gestão e o trabalho dos meios de comunicação. No sentido de analisar de forma crítica o futuro dos meios de comunicação social na vida mediática, sugiro que temos de conceptualizar claramente o que significa viver nos meios de comunicação e quais são os desafios e oportunidades que essa vida pode trazer às indústrias e aos profissionais da comunicação social. Leah Lievrouw e Sonia Livingstone (2004) propõem um novo quadro abrangente para conceptualizar o papel que os (novos) meios de comunicação desempenham na sociedade, na indústria e na vida quotidiana, considerando os meios de comunicação como infraestruturas em funcionamento por baixo, através e em pano de fundo nas estruturas sociais. Como infraestruturas, defendem as autoras, os meios de comunicação incorporam "os artefactos ou dispositivos usados para comunicar ou transmitir informação, as atividades e práticas empreendidas pelas pessoas para comunicar ou partilhar informação e as organizações sociais ou formas de organização que se desenvolvem em torno desses dispositivos e práticas" (7; itálico acrescentado). O que esta definição tem de poderoso é que inclui as abordagens existentes que externalizariam os meios de comunicação, reconhecendo, ao mesmo tempo, a forma como os meios de comunicação se tornaram parte integrante, enquanto 
In (often futile) attempts to tame the unruly beast of contemporary media culture, the media industry has consolidated over the past few decades, with global investors, holding firms, and multinational corporations gobbling up companies, studios and publishers at an accelerated pace, quickly followed by managerial regimes intended to standardize and streamline practices across their networks. The assumption behind all of this has been that by integrating and converging previously separated elements of the media industry - notably production and marketing, audience development and content strategy, business and creative - the traditionally insular and often idiosyncratic nature of media work would become more flexible, consumer-focused, and able to move with the market between and across a variety of media platforms and channels.

The paradox of these developments is that in media life, media professionals should be having a field day with their work, as people are clearly emotionally engaged with all their media, and the cross-platform digital data generated in media life promises precise targeting of skillfully crafted messages to eager audiences. Yet the opposite seems to be true: people seem happier spending time on their own media - that is: online social networks (such as Facebook or WeChat), and the outlook for work the industry is becoming profoundly precarious, forcing media professionals to be 'entrepreneurial' (Cohen, 2015) which more often than not euphemistically covers working conditions that can be best understood as exploitative and uncertain.

It is safe to say these are complex times for media management and work. In order to critically analyze the future of media in media life, I suggest we have to conceptualize clearly what it means to live in media, and what challenges and opportunities such a life may bring to media industries and professionals. Leah Lievrouw and Sonia Livingstone (2004) propose a comprehensive framework for conceptualizing the role (new) media play in society, industry and everyday life, considering media as infrastructures that run underneath, through, and in the background of social structures. As infrastructures, they argue, media incorporate "the artifacts or devices used to communicate or convey information, the activities and practices in which people engage to communicate or share information, and the social arrangements or organizational forms that develop around those devices and practices" (7; italics added). The power of this definition is that it includes existing approaches that would externalize media, while recognizing how media have also become an integral part as building blocks (to continue the architectural reference) for everyday life. When considering the history as well as the contemporary role of media, one would always have to consider these three principal components - media as artifac$\mathrm{ts}$, activities, and arrangements - in conjunction.

To Lievrouw and Livingstone's foundational work I would add an interpretation of media as not just material, but also emotional infrastructures. Media are material in their existence as devices, platfor$\mathrm{ms}$, hardware, software, contents and services - yet they are also emotional in terms of how we make sense of 
elementos constitutivos (continuando com a referência à arquitetura), da vida quotidiana. Ao considerar a história e o papel contemporâneo dos meios de comunicação, deve sempre considerar-se estes três componentes principais - os meios de comunicação como artefactos, atividades e organizações - em conjunto.

Ao trabalho fundamental de Lievrouw e Livingstone, eu acrescentaria uma interpretação dos meios de comunicação não só como estruturas materiais, mas também emocionais. Os meios de comunicação são materiais na sua existência enquanto dispositivos, plataformas, hardware, software, conteúdos e serviços - contudo, são igualmente emocionais na forma como nos entendemos e aos outros através do testemunho mediado, na forma como estruturam e organizam as interações quotidianas e naquilo que geralmente sentimos em relação aos meios de comunicação (e, nos meios de comunicação, em relação uns aos outros e ao mundo em que vivemos). Os meios de comunicação não são 'máquinas frias' que simplesmente permitem a telecomunicação e a mediatização - os meios de comunicação têm tanto de equipamento quanto de emoção, tanto suscitam afeto como oferecem possibilidades. De ora em diante, usarei cada um destes elementos na definição de meio de comunicação com vista a traçar um desafio estético, ético e em matéria de responsabilidade social para os meios de comunicação social (e o seu futuro). Esta análise é uma extensão de trabalhos anteriores em que debati as implicações da vida mediática para a indústria publicitária (ver Deuze, 2016).

\section{Os meios de comunicação como artefactos: os meios de comunicação estão em todo o lado.}

Embora esteja fora do âmbito deste ensaio proceder a uma análise geral da evolução dos meios de comunicação enquanto artefactos, pode dizer-se com segurança que os meios de comunicação cumprem, de facto, os critérios da teoria científica da evolução: no decurso da história dos meios de comunicação, os nossos artefactos multiplicaram-se exponencialmente - todos os anos temos mais, e não menos, meios de comunicação à nossa disposição - e estes dispositivos tornam-se cada vez mais diferenciados e complexos. Os meios de comunicação convergem e divergem a um ritmo acelerado, muitas vezes não necessariamente progredindo ao longo de trajetórias lineares simples, com diferentes 'espécies' de meios de comunicação a tornarem-se dominantes, não exclusivamente assentes na qualidade objetiva das suas características - sendo a sua sobrevivência frequentemente mais bem explicada pela sua adequação ao respetivo ambiente. 
ourselves and others through mediated witnessing, how media structure and arrange daily interactions, and what we generally feel about media (and, in media, about each other and the world we live in). Media are not 'cold machines' that simply enable telecommunication and mediatization - media are equipment as much as emotion, they elicit affect as much as they offer affordances. Hereafter I use each of these elements in the definition of media to outline a particular aesthetic, ethical, and social responsibility challenge for (the future of) media. This analysis is an extension of earlier work where I discussed the implications of media life for the advertising industry (see Deuze, 2016).

\section{Although a general review of the}

evolution of media

as artifacts is

beyond the scope of

this essay, it is safe

to say that media

do meet criteria

of the scientific

theory of evolution

\section{Media as Artefacts: \\ Media are Everywhere}

Although a general review of the evolution of media as artifacts is beyond the scope of this essay, it is safe to say that media do meet criteria of the scientific theory of evolution: in the course of media history our artifacts have exponentially multiplied every year there are more, not fewer media at our disposal - and these devices become more differentiated and complex all the time. Media converge and diverge at a rapid pace, often not necessarily progressing along neat linear trajectories, with different media 'species' becoming dominant not exclusively based on the objective quality of their features - their successful survival often better explained by fitness with their environment.

The ubiquity and pervasiveness of contemporary media render them almost invisible - it is hard to notice or remember what specific activity you are involved in using what particular function of what distinct device. Added to this must be a recognition of the growing role of machine-to-machine communications in a contemporary 
A ubiquidade e penetração dos meios de comunicação contemporâneos tornam-nos praticamente invisíveis - é difícil reparar ou relembrar em que atividade específica estamos envolvidos ao utilizar determinada função de determinado dispositivo específico. Acresce a isto um reconhecimento do papel cada vez mais relevante das comunicações máquina a máquina num contexto contemporâneo da Internet das coisas. Os meios de comunicação não só se tornam omnipresentes nas nossas vidas porque os usamos (e gostamos deles) muito - os meios de comunicação dão origem a meios de comunicação. Em suma, defendo que a evolução dos meios de comunicação enquanto artefactos sugere uma experiência vivida, cada vez mais integral e ambiente, de vários meios de comunicação à medida que navegamos pela vida quotidiana.

De um ponto de vista criativo, a evolução dos meios de comunicação enquanto artefactos para um universo dos 'meios de comunicação em todo o lado' é bastante entusiasmante. Mais especificamente, um ambiente de meios de comunicação digitais omnipresentes e ubíquos pode inspirar novas formas de narrativa, conjugando histórias e experiências dentro e entre meios de comunicação, num reconhecimento do comportamento migratório, móvel e plurilocal das pessoas. Aqui é possível fazer-se uma distinção entre práticas de narrativa multimedia, crossmedia e transmedia para os profissionais mediáticos, estando cada uma destas abordagens potencialmente associada a modos de narrativa participativos (em que o cidadão-consumidor participa, contribuindo para uma ou mais fases do processo de produção). Embora estes modos de narrativa, resumidamente analisados mais abaixo, não sejam necessariamente novos, com a digitalização contínua tanto do trabalho mediático como da vida mediática surgem oportunidades inspiradoras para conceber e produzir formas inovadoras de ligar pessoas, conteúdos e serviços.

Na narrativa multimedia, a produção de uma história pode assumir inúmeras formas - palavra falada ou escrita, música, fotografia e vídeo, animações, ilustrações e infográficos -, contudo, é geralmente produzida num canal específico (como um sítio web). No jornalismo, referimo-nos por vezes a isto como a "snowfallização' (do inglês "snowfalling") das notícias - numa referência respeitosa a uma abrangente reportagem multimédia com o título "Snow Fall” no New York Times (publicada em dezembro de 2012). A série de vários capítulos sobre os acontecimentos em torno de uma avalanche fatal integrava vídeos, fotografias e gráficos de uma forma natural, fluindo o conteúdo de forma praticamente contínua ao longo da página.

Outra opção para os contadores de histórias associa o potencial de diferentes formas mediáticas à oportunidade de alcançar e envolver públicos em mais do que apenas um canal. Na realidade, esta narrativa crossmedia pega numa história e conta-a de formas específicas que sejam as mais adequadas ao canal em que é publicada. Levando estas tendências ainda mais longe, a narrativa transmedia - termo cunhado por Henry Jenkins (2003) e posteriormente desenvolvido por Carlos Alberto Scolari (2009) - sugere 
context of the internet of things. Media do not just become omnipresent in our lives because we use (and like) them a lot - media beget media. All in all I contend that the evolution of media as artifacts suggests an increasingly seamless and altogether ambient lived experience of multiple media as we navigate everyday life.

From a creative point of view, the evolution of media as artefacts into a 'media everywhere' universe is quite exhilarating. Specifically, a pervasive and ubiquitous digital media environment can inspire new forms of storytelling, combining stories and experiences within and across media in an recognition of people's migratory, mobile and multisited behavior. Here a distinction can be made between multimedia, crossmedia and transmedia storytelling practices for media professionals, each of these approaches potentially coupled with participatory modes of storytelling (where the citizen-consumer comes in to contribute to one or more phases of the production process). Although these modes of storytelling, as briefly reviewed below, are not necessarily new, with the on-going digitisation of both media work and media life come inspiring opportunities to design and produce innovative ways to connect people, content and services.

In multimedia storytelling, the production of a story can take on many forms - spoken and written word, music, photography and video, animations, illustrations and infographics - yet generally is produced within one specific channel (cf. a website). In journalism, this is sometimes referred to as 'snowfalling' the news - a respectful reference to a comprehensive multimedia reportage titled "Snow Fall" by the New York Times (published December, 2012). The multi-chapter series on events surrounding a deadly avalanche integrated video, photos, and graphics in a natural way, with content almost seamlessly flowing across the page.

Another option for storytellers combines the potential of different media forms with the opportunity to reach and engage audiences across more than just one channel. In effect, such crossmedia storytelling takes a story and tells it in ways particular to the form best suited for the channel it gets published on. Taking these trends even further, transmedia storytelling - a term coined by Henry Jenkins (2003) and further developed by Carlos Alberto Scolari (2009) suggests outsourcing some creative agency to the media user as the idea of a complete and finished full story is abandoned in favor of a multi-platform array of multiple stories, using different media forms, appearing in as many channels.

New multimedia, crossmedia and transmedia modes of storytelling inspire so much more than the production of a one-off, finished story. Instead, media professionals are faced with the option to design content and experiences across platforms, integrating user-generated content, and expanding the reach of the storyline beyond its initial publication. I would call this a fundamental aesthetic opportunity in media life: a chance to tell better stories, using multiple media in complex and exciting ways, integrating the co-creativity of consumers. In other words: taking media work as an art form as well as a craft seriously. 
afetar alguma ação criativa ao utilizador dos meios de comunicação, na medida em que a ideia de uma história completa e acabada é abandonada a favor de uma série de várias histórias em diferentes plataformas, recorrendo a diferentes formas mediáticas e que aparecem em inúmeros canais.

Os novos modos de narrativa multimedia, crossmedia e transmedia inspiram muito mais do que a simples produção de uma história pontual, acabada. Ao invés disso, os profissionais mediáticos deparam com a opção de conceber conteúdos e experiências em várias plataformas, integrando conteúdos criados por utilizadores e ampliando o alcance da história para além da sua publicação inicial. Chamaria a isto uma oportunidade estética fundamental na vida mediática: uma oportunidade de contar histórias melhores, usando vários meios de comunicação de formas complexas e empolgantes, integrando a cocriatividade dos consumidores. Por outras palavras: levar a sério o trabalho mediático enquanto forma de arte bem como enquanto ofício.

\section{Os meios de comunicação enquanto atividades: os meios de comunicação são aquilo que fazemos}

Para além dos meios de comunicação enquanto artefactos, há as inúmeras formas em que as pessoas os usam. Face ao ambiente mediático cada vez mais complexo, Graham Meikle e Sherman Young vão ao ponto de observar que "para muitas pessoas, os meios de comunicação social já não são apenas aquilo que veem, ouvem ou leem — os meios de comunicação são agora aquilo que as pessoas fazem" (2012: 10). Relativamente ao que as pessoas fazem, a gama de atividades mediadas tornou-se praticamente tão multiplicada e diversificada quanto os diferentes tipos de artefactos mediáticos utilizados. Uma visão panorâmica sobre a forma como as pessoas usam os meios de comunicação numa variedade de contextos por todo o mundo sugere, de facto, algo que, não obstante, é universal: quanto mais usamos os meios de comunicação, menos provável é que o façamos de forma deliberada. Na maioria dos países do globo, os relatórios e estudos sobre a quantidade de tempo em que as pessoas usam os meios de comunicação são mais ou menos semelhantes: praticamente todo o tempo de que dispomos é passado com os meios de comunicação, seja diretamente (a folhear uma revista, fazer um telefonema, ouvir um programa na rádio, navegar num sítio web específico, e assim por diante) ou indiretamente (tendo música, imagens e vídeo como pano de fundo ao atravessar espaços públicos, um computador ou telemóvel sempre ligado, rodeados por tecnologias que captam, registam e arquivam os nossos comportamentos). Todavia, quando questionadas, as pessoas tendem a esquecer-se da maioria dos meios de comunicação que utilizam, essencialmente porque estão simultaneamente expostas a vários meios de comunicação e, na maioria dos casos, a utilização está associada a outras atividades do quotidiano, como trabalhar, socializar e comer.

A natureza mundana da utilização dos meios de comunicação tem propriedades adicionais, que vão além da sua simultaneidade e, em geral, do seu caráter pouco deliberado. Vejamos os verbos empregues para descrever as principais atividades mediáticas das pessoas ao longo de grande parte do 
Would call this

a fundamental

\section{aesthetic}

\section{opportunity in}

media life: $a$

chance to tell

better stories,

using multiple

media in complex

and exciting ways

\section{Media as Activities: Media are What We Do}

Beyond media as artefacts are the many different ways people use media. Given the increasingly complex media environment, Graham Meikle and Sherman Young go as far to observe that "For many people, the media are no longer just what they watch, listen to or read - the media are now what people do" (2012: 10). In terms of what people do, the range of mediated activities has become almost as multiplied and diversified as the various kinds of media artifacts used. A bird's eye view of how people use media in a variety of contexts around the world does suggest something universal, though: the more we use media, the less likely we are to be deliberate about it. In most countries around the world, reports and studies on the amount of time people use media are more or less similar: almost every waking moment is either directly (paging through a magazine, making a phone call, tuning in to a show on the radio, surfing to a particular website, and so on) or indirectly (having music, images, and video in the background while traversing public spaces, a computer or mobile phone in always-on mode, surrounded by technologies that capture, record, and archive our behaviors) spent with media. Yet when asked about it, people tend to forget most of their media use, mainly because they are concurrently exposed to multiple media at the same time, and most of their media use occurs combined with other everyday activities such as working, socializing, and eating.

The mundane nature of media use has additional properties beyond its concurrence and generally less-than-deliberateness. Consider the verbs deployed to describe people's principal media activities throughout much of the (offline) 20th century: reading, listening, viewing, typing, zapping, and calling. In today's online media environment, one has to add to this list activities such as: cutting, pasting, editing, forwarding, linking, liking, chatting, texting, zipping, (re-) mixing, redacting, uploading (and downloading), sharing, rating, recommending, commenting - so on, so forth. In 2008 web usability consultant Jakob Nielsen coined the distinction between these two types 
séc. XX (offline): ler, ouvir, ver, digitar, fazer zapping e ligar. No ambiente mediático online dos dias de hoje, é necessário acrescentar a esta lista atividades como cortar, colar, editar, reencaminhar, hiperligar, pôr um gosto, conversar, enviar mensagens, zipar, (re) misturar, redigir, carregar (e transferir), partilhar, classificar, recomendar, comentar - e assim por diante. Em 2008, o consultor em usabilidade da web Jakob Nielsen cunhou a distinção entre estes dois tipos de atividades em termos de meios de comunicação que induzem uma atitude passiva (lean-ba$c k$ - reclinar-se para trás) por oposição aos meios que induzem uma atitude ativa (lean-forward - inclina-se para a frente). Para além do significado destes conceitos - que articulam a natureza física da utilização que fazemos dos meios de comunicação -, a distinção de Nielsen assinala uma mudança subtil nas atividades mediáticas, passando-se das atividades que têm uma natureza essencialmente de consumo, para um conjunto de comportamentos que se afiguram mais produtivos, já para não dizer criativos. Na vida mediática, utilizar os meios de comunicação equivale a fazer meios de comunicação - muitas vezes sem uma intenção (e autorização) deliberada do utilizador. Não serve isto para privilegiar exclusivamente o tipo de criatividade exposta por parte de quem escreve ou edita entradas na Wikipedia, cria e partilha os seus próprios vídeos no Youtube e no Vimeo e que, de outras formas, se envolve em formas 'físicas' de criatividade. Este é um grupo relativamente pequeno quando comparado com a grande maioria dos utilizadores dos meios de comunicação que se tornaram criativos de uma forma ou outra, sem necessariamente se aperceberem disso, participando na criatividade 'virtual' da construção de uma realidade social nos meios de comunicação que é diferente daquela que é simplesmente consumida.

Considerar os meios de comunicação como aquilo que fazemos abre espaço para futuras explorações em que os meios de comunicação geram qualidades mais humanas, na medida em que, literalmente, se estão a aproximar das nossas vidas íntimas e mais pessoais. Em vez de os vermos à distância, na sala de estar ou num quiosque ou biblioteca, os meios de comunicação atuais estão nos nossos bolsos e cada vez mais próximos do nosso corpo. Ao invés de nos limitarmos a obter informações, através dos meios de comunicação, acerca dos profissionais privilegiados que fazem a política e os negócios, sentimos, nos meios de comunicação, emoções tão profundas como amor, deslumbre, ódio e desejo relativamente a pessoas que conhecemos, pessoas como nós. Projetando que os meios de comunicação, no futuro, se transformariam naquilo que as pessoas fazem, Mark Balnaves, Debra Mayrhofer e Brian Shoesmith, em 2004, propuseram um 'novo humanismo' em todas as profissões mediáticas, tendo em consideração uma reconfiguração da relação entre organizações e públicos "devido a colapsos de empresas e a catástrofes ambientais e de outras naturezas criadas pelas corporações [...] ao aumento das tecnologias participativas; e [...] ao facto de os públicos não quererem participar em técnicas modernas de consulta e avaliação do mercado" (p. 191-2). Afirmavam que tal humanismo poderia ser considerado um antídoto para o pensamento corporativo do tipo 'tamanho único', favorecendo, em alternativa, uma abordagem mais envolvida, crítica e interativa e, sugeriam os autores, "uma forma de vida mais espiritual e ética" (p. 200). 
of activities in terms of lean-back versus lean-forward media. Beyond the significance of these concepts - in articulating the embodied nature of our media use - Nielsen's distinction marks a subtle shift in media activities from those that are primarily consumptive in nature, to a range of behaviors that seem more productive, if not to say: creative. In media life, media using equals media making often without deliberate intent (and consent) of the user. This is not to exclusively privilege the kind of creativity on display by those who write or edit Wikipedia entries, create and share their own videos on Youtube and Vimeo, and are otherwise engaged in such 'hard' forms of creativity. This is a relatively small group compared to the vast majority of media users that have become creative in one way or another without necessarily realizing it, participating in the 'soft' creativity of constructing a social reality in media that is different from one that is simply consumed.

Considering media as what we do opens up space for future explorations where media beget more human qualities as they are quite literally moving in closer to our most personal, intimate lives. Rather than viewing them at a distance in the living room or at a kiosk or library, today's media are in our pockets and ever so close to our bodies. Instead of just learning through media about the privileged professionals that make up politics and business, we experience in media such profound emotions like love, wonder, hate, and desire regarding people we know, people like us. Projecting the development of media becoming what people do into the future, Mark Balnaves, Debra Mayrhofer and Brian Shoesmith in 2004 proposed a "new humanism' in all media professions, considering a reconfiguration of the relationship between organizations and publics "because of corporate collapses and environmental and other disasters created by corporations [...] the rise of participatory technologies; and [...] because audiences do not want to participate in modern surveying and market evaluation techniques" (p. 191-2). They argued how such a humanism could be considered to be an anti-dote to corporate 'one-size-fits-all' thinking, instead favoring a more engaged, critical, and interactive approach and, the authors suggest, "a more spiritual and ethical way of life" (p. 200).

In the Summer of 2015 the American Press Institute published the results of its survey among 10,481 alumni of 22 prominent schools of journalism and (mass) communication - the primary gateway to careers in the media. One of the most remarkable conclusions from this study was the fact that these media professionals identified ethics as the most critical skill in their workplace, with 84 percent citing it as very important. There is a direct link between media collapsing into the lifeworld and media professions potentially embracing a new humanism or at least human-centered way of working: ethics. The fundamental issue for media professions in media life related to the way people use media comprises an ethical opportunity. Doing the right thing in a digital culture is of key importance where, as for most people their lives are played out in public forever more. Media professionals have a chance 
No verão de 2015, o American Press Institute publicou os resultados do inquérito que realizou a 10481 ex-alunos de 22 conhecidas faculdades de jornalismo e comunicação (de massas) - a principal porta de entrada para as carreiras nos meios de comunicação. Uma das conclusões mais notáveis deste estudo foi o facto de estes profissionais mediáticos terem identificado a ética como a competência mais essencial no seu local de trabalho, com 84 por cento dos inquiridos a citá-la como muito importante. Há uma ligação direta entre o facto de os meios de comunicação se terem transformado no mundo da vida e o facto de as profissões mediáticas potencialmente adotarem um novo humanismo ou, pelo menos, uma forma de trabalhar centrada no ser humano: a ética. A questão fundamental para as profissões mediáticas na vida mediática relacionada com a forma como as pessoas usam os meios de comunicação engloba uma oportunidade ética. Fazer o que é correto numa cultura digital é de importância primordial, na medida em que, para a maioria das pessoas, as suas vidas se desenrolam cada vez mais em público. Os profissionais mediáticos têm uma oportunidade de considerar a ética de reunirem e manipularem, de forma aberta, as sombras digitais das pessoas enquanto as suas vidas se movimentam online; de apreciarem a ética associada ao esbatimento permanente das fronteiras entre a informação independente (geralmente considerada como parâmetro de referência do jornalismo de qualidade) e a experiência patrocinada do conteúdo de marca.

Neste contexto, importa ponderar de forma crítica a descoberta do novo humanismo e da experiência humana por parte dos profissionais mediáticos. Um desafio ético seria evitar uma vida mediática em que toda e qualquer pessoa, enquanto utilizadora dos meios de comunicação, se tornasse um produto; assumir uma posição contra uma vida mediática tão imbuída de experiências de marca infinitas que se torna uma vida consumista, orientada pela fórmula (nas palavras memoráveis de Zygmunt Bauman): “não há consumidor que não seja mercadoria" (2007: 12). Transformemos o desafio ético numa oportunidade - uma oportunidade para o trabalho mediático se empenhar em promover um mundo melhor, apoiar a gestão socialmente responsável das empresas e defender os direitos e a soberania do consumidor.
A dimensão ética do trabalho mediático na vida mediática diz essencialmente respeito à totalidade da experiência humana enquanto potencial experiência de marca (e marcada). Isto levanta a questão de se saber em que contexto e organização social funciona o trabalho mediático.

\section{Os meios de comunicação enquanto organizações: vivemos nos meios de comunicação}

Em 2006, a revista Time declarou-nos a todos - "YOU" - como Pessoa do Ano, apresentando na capa um ecrã do YouTube que funcionava como espelho. A pessoa que segurasse a revista à sua frente estaria a olhar para si própria. A centralidade de nós próprios na assunção da responsabilidade pela reconstrução do mundo e das nossas vidas no mesmo através dos meios de comunicação (e da forma como os usamos) não pode ser subestimada. No seu trabalho, José van Dijck (2009) realça a conjugação da autoexpressão, da autocomunicação (de massas) e da autopromoção nos 
to consider the ethics of open-ended gathering and manipulating of people's digital shadows as their lives move online. To appreciate the ethics of permanently blurring the boundaries between independent information (generally considered to be the benchmark for quality journalism) and the sponsored experience of branded content.

In this context we have to critically consider the discovery of new humanism and the human experience by media professionals. An ethical challenge would be to prevent a media life where each and every person, as a media user, becomes a product. To take a stand against a media life so fused with infinite branding experiences that it becomes a consuming life, driven by the formula (in the memorable words of Zygmunt Bauman): "no consumer unless a commodity" (2007: 12). Let uss turn the ethical challenge into an opportunity - a chance for media work to be committed to promoting a better world, supporting socially responsible corporate governance, and advocating for consumer rights and sovereignty.
The centrality

of ourselves as

having to take

responsibility for

reconstructing

the world and our

lives in it through

(the way we use)

media cannot be

underestimated
The ethical dimension of media work in media life relates primarily to the totality of the human experience as a potential branding (and branded) experience. This raises the question, in what social context and arrangement media work functions.

\section{Media as Arrangements: We Live in Media}

In 2006 Time magazine declared all of us - "YOU" - as its annual Person of the Year, featuring a front cover with a YouTube screen functioning as a mirror. The person holding up the magazine would be looking at herself. The centrality of ourselves as having to take responsibility for reconstructing the world and our lives in it through (the way we use) media cannot be underestimated. In her work, José van Dijck (2009) highlights the conflation of self-expression, (mass) self-communication and self-promotion at work in social media, as the majority of our time in media gets spent with ourselves (and each other) directly or indirectly on social platforms: "After all, social 
meios de comunicação, na medida em que a maioria do nosso tempo nestes é passado connosco próprios (e uns com os outros) direta ou indiretamente em plataformas sociais: "Afinal de contas, as redes sociais não são palcos neutros de autorrepresentação - são as próprias ferramentas para moldar identidades" (213).

Por um lado, afigura-se, de facto, que o trabalho mediático privado das pessoas na vida mediática gira essencialmente em torno do trabalho identitário. O número de "eus" digitais prolifera - desde processos médicos a bases de dados de registo online, desde serviços voluntários de cartão de cliente até aos arquivos dos fornecedores de telecomunicações, desde os scanners, monitores e câmaras omnipresentes até ao fenómeno das selfies e do check-in em determinados locais, tão comum nas redes sociais móveis. Um aspeto contemporâneo crucial da relação entre o eu e a identidade social prende-se com a hábil manutenção de vários “eus" em simultâneo no mundo, podendo cada um deles ter um impacto profundo em quem (pensamos que) somos. Tal trabalho identitário pode inspirar uma autodisciplina incessante numa tentativa de nos enquadrarmos - em todo o lado. Face ao exposto, numa sociedade de "eus" multiplicados, os meios de comunicação são todo-poderosos enquanto agentes de doçura opressiva e coletividade autossemelhante. Ao mesmo tempo, os meios de comunicação podem permitir uma experiência libertadora, retirando o eu de regimes opressivos de controlo externo, em vez de oferecer pelo menos um mínimo de possibilidade de atuação individual - tal como é exemplificado pelo domínio que temos sobre as definições de privacidade nos sítios das redes sociais online ou através da manipulação das definições de partilha da localização num smartphone. É evidente que este domínio tende a permanecer confinado a enclaves corporativamente controlados online (e offline). Um elemento dos meios de comunicação como organização social diz respeito à natureza distinta do indivíduo à medida que se movimenta pelo mundo. As relações com os outros (e com o mundo em geral) em tal cenário são filtradas por interfaces, algoritmos, definições de software e especificações de hardware do 'espaço de informação pessoal' que criamos à nossa volta. Este espaço é aquilo a que Peter Sloterdijk (2004) chama uma mediasphere, que forma uma concha eletrónica invisível à nossa volta, através da qual a totalidade da nossa experiência dos outros é mediada. Sloterdijk parece estar convencido de que a vida numa bolha de meios de comunicação deixa as pessoas cegas à coexistência.

Para além do individual, a nossa experiência do social na vida mediática cria uma personagem mediada distinta - uma personagem que é completamente confusa e complicada, embora sempre e ostensivamente associada à ligação e à conectividade. Quer se trate da experiência fantástica de assistir a um concerto ou casamento, em que mais pessoas parecem estar a gravar o evento do que a testemunhá-lo de facto, quer seja simplesmente a tentativa de articular um sentido mais ou menos coerente do eu, os meios de comunicação estão indissociavelmente ligados, enredados e envolvidos na realidade social. Neste processo, os meios de comunicação vêm organizar estas realidades: adicionando perspetivas e dimensões (ofuscando outras ao mesmo tempo), introduzindo (e excluindo) outros em eventos sem 
media are not neutral stages of self-performance - they are the very tools for shaping identities" (213).

On the one hand, it indeed seems as if peoples' private media work in media life revolves primarily around identity work. The number of digital selves proliferate - from medical dossiers to online registration databases, from voluntary customer card services to the archives of telecom providers, from omnipresent scanners, monitors and cameras to the selfie and location check-in phenomenon so common in mobile media. A crucial contemporary aspect of the relationship between self and social identity is the skillful maintenance of the multiple selves existing in the world, each of which can have a profound impact on who we (think we) are. Such identity work may inspire incessant self-disciplining in an attempt to fit in - everywhere. By this account, in a society of multiplied selves media are all-powerful as agents of oppressive blandness and self-similar collectivity. At the same time, media can provide a liberating experience, lifting the self up from oppressive regimes of external control, instead offering at least some modicum of individual agency - as exemplified by one's mastery over the privacy settings at online social networking websites or through manipulating location-sharing settings on a smartphone. Of course, such mastery tends to remain confined to corporately controlled online (and offline) enclaves. One element of media as a social arrangement refers to the distinct nature of the individual as she moves through the world. The relationships with others (and with the world at large) in such a scenario are all filtered through the interfaces, algoritms, software settings, and hardware specifications of the 'personal information space' we create around ourselves. This space is what Peter Sloterdijk (2004) calls a mediasphere, forming an invisible electronic shell around us whereby our entire experience of others becomes mediated. Sloterdijk seems convinced life in a bubble of media leaves people blind to coexistence.

Beyond the individual, our experience of the social in media life begets a distinct mediated character
- a character that is altogether confusing and complicated, yet always and ostensibly about connection and connectivity. Whether it is the uncanny experience of attending a concert or marriage at which more people seem to be recording the event than in fact witnessing it, or simply by trying articulate a more or less coherent sense of self: media are inextricably linked, enmeshed, and involved with social reality. In this process, media come to arrange such realities: adding perspectives and dimensions (while obfuscating others), introducing (and excluding) others into events without necessarily being co-present, enable participation in otherwise (or formerly) utilitarian experiences of life. All such experiences are ultimately about connection: recording a slice of life to impart it to others, uploading a preferred self to seek recognition from others, witnessing and to be witnessed by others. Perhaps our personal information space is not so much blind to coexistence, but rather overstimulated by it?

It needs to be emphasized, once more, how difficult it is for anyone to not just be able to manipulate 
estarem necessariamente também presentes, permitindo a participação em experiências de vida que, de outra forma (ou anteriormente), seriam utilitárias. Todas estas experiências, em última análise, têm a ver com a ligação: registar uma parte da vida para partilhá-la com os outros, carregando para a Internet um eu preferido no sentido de procurar o reconhecimento dos outros, testemunhando e sendo testemunhado por outros. Talvez o nosso espaço de informação pessoal não seja assim tão cego à coexistência, mas seja antes excessivamente estimulado por ela.

Importa realçar, uma vez mais, como é difícil para alguém o facto de não só ser capaz de manipular e controlar o seu ambiente mediático, mas também de compreender e supervisionar as (potenciais) implicações da utilização que faz dos meios de comunicação - quer se trate de um comportamento relativamente benigno, como optar por transferir um ficheiro torrent ou ver um filme online, quer envolva a participação ativa nos grandes movimentos sociais da nossa época, como a Primavera Árabe, os Indignados, o Okupa e o \#BlackLivesMatter (apenas para indicar alguns), impossíveis de imaginar sem o papel infraestrutural que os meios de comunicação pessoais, em rede e móveis desempenham para proporcionar os contornos de tais protestos.

A forma como os meios de comunicação se enquadram em todos os aspetos da nossa vida - fazendo com que qualquer tipo de vida fora dos mesmos seja objeto de imaginação e ilusão em vez de uma realidade com que podemos trabalhar - deveria fazer subir a parada relativamente à forma como a indústria se pode ver e posicionar no mundo. Em geral, as profissões mediáticas têm um papel profundo a desempenhar na vida mediática, quanto mais não seja porque se pode considerar que estes profissionais estejam mais capacitados para viverem as suas vidas nos meios de comunicação. Um poder de comunicação de tal envergadura está associado a uma enorme responsabilidade. Que tipo de mundo e de visão do mundo é que os meios de comunicação social, enquanto indústria, produzem e em que medida estarão os profissionais mediáticos cientes da visão do mundo que o seu trabalho e as plataformas onde vive o seu trabalho promovem?
Para ser possível avaliar as ramificações de tudo isto, seria necessário ter em consideração a obra de Don Ihde (1990), na medida em que o autor defende que, ao longo da história, as culturas e as sociedades humanas têm sido tecnologicamente incorporadas e que essas tecnologias, por seu turno, transformam o mundo da vida humana. Ihde realça a forma como as relações entre pessoas, o mundo (natural e social) onde vivem e as tecnologias que usam são medidas através de uma intencionalidade tecnológica (141). Por outras palavras, as tecnologias de informação e comunicação que usamos não são agentes neutros, apresentando-se antes com possibilidades específicas, com determinadas expetativas sobre quem somos e o que devemos fazer. Jos de Mul usa um argumento semelhante, fazendo referência específica aos meios de comunicação, na medida em que "cada meio transporta consigo a sua própria visão do mundo ou metafísica" (2010: 89). Para De Mul, a visão essencial do mundo que obtemos do nosso atual conjunto de meios de comunicação assenta nas suas principais características de serem multimédia, interativos e capazes de virtualizar a 
and control their media environment, but also to understand and oversee the (potential) implications of their media use - whether it is relatively benign behavior such as choosing to download a torrent file or streaming a movie, or involves one's active participation in the great social movements of our time like the Arab Spring, the Indignados, Occupy Together, and \#BlackLivesMatter (to name but a few), impossible to imagine without the infrastructural role personal, networked and mobile media play in providing the contours of such protests.

The way media fit into all aspects of our lives - making any kind of life outside of media the object of imagination and illusion rather than a reality one can work with - should raise the stakes for the way the industry can see and position itself in the world. Media professions in general have a profound role to play in media life, if only because these professionals can be considered to be better skilled at living their lives in media. Such great communication power comes with great responsibility. What kind of world and worldview

\section{Media professions} in general have a profound role to play in media life, if only because these professionals can be considered to be better skilled at living their lives in media does the media as an industry produce, and to what extent are media professions aware of the worldview their work and the platforms upon their work lives promote?

In order to appreciate the ramifications of this, one could consider the work of Don Ihde (1990) as he argues that, throughout history, human cultures and societies have been technologically embedded and that those technologies in turn transform the human lifeworld. Ihde emphasizes how the relations between people, the (natural and social) world they live in, and the technologies they use are mediated through a technological intentionality (141). In other words: the information and communication tecnologies we use are not neutral agents, but come with specific affordances, with certain expectations of who we are and what we are supposed to do. Jos de Mul makes a similar point with specific reference to media in that "every medium carries with it its own distinctive worldview or metaphysics" (2010: 89). For De Mul, the essential worldview we get from our current media mix is based on their 
realidade. Na vida mediática, o mundo torna-se simultaneamente real e virtual, na medida em que a vida online e offline extravasam uma para a outra - processo cultural descrito por Manuel Castells (2010[1996]) como virtualidade real, em que o mundo online das aparências se torna parte da experiência quotidiana vivida em vez de apenas existir nos ecrãs dos nossos computadores ou televisores. Vejo isto como uma responsabilidade social, para os profissionais mediáticos - e os estudantes e académicos que estudam o que os profissionais mediáticos e as suas indústrias fazem - estarem mais cientes da materialidade do seu trabalho.

\section{Discussão}

No que se refere à gestão e à organização do trabalho, as empresas e as carreiras nos meios de comunicação social podem ser consideradas bastante especiais, em parte devido a este equilíbrio delicado e contestado entre a autonomia criativa dos criadores de cultura e a gestão instrumental de empresas comerciais.
Zygmunt Bauman (2005) considera a relação entre o comércio e a cultura uma rivalidade entre irmãos, na medida em que o "enredo da gestão contra a liberdade endémica da cultura é um casus belli perpétuo. Por outro lado, os criadores de cultura precisam de gestores caso queiram... ser vistos, ouvidos, escutados e caso queiram ter hipótese de ver o seu trabalho/projeto concluído" (55).

$\mathrm{O}$ que aqui defendo, em relação ao futuro dos meios de comunicação social enquanto indústria no contexto da vida mediática, é que os meios de comunicação têm a possibilidade de usar os desafios contemporâneos como oportunidades para adotarem um papel mais crítico, ético e socialmente responsável neste mundo. Dito isto, é necessário abordar, de um ponto de vista crítico, duas dimensões essenciais do trabalho mediático: o seu contexto laboral precário e a necessidade de os utilizadores dos meios de comunicação terem acesso a (e serem confrontados com) um leque alargado de conteúdos e experiências, especialmente no tocante a notícias e informações sobre o mundo em que vivem. Quanto à primeira dimensão, é necessário investigar o que faz felizes os profissionais mediáticos e de que forma a indústria pode promover esta felicidade - seguindo a tese de que trabalhadores felizes são mais produtivos e produzem trabalho de qualidade (Hesmondhalgh e Baker, 2011; von Rimscha, 2015). Relativamente à segunda dimensão, é crucial investir em literacia mediática e em tornar as crianças conhecedoras dos meios de comunicação, na medida em que esta literacia é aquilo que John Hartley designa de literacia multimédia, que implica não apenas analisar criticamente os conteúdos dos meios de comunicação, mas também adquirir competências para produzi-los de forma semiprofissional. Como afirma Hartley, "a era dos meios de comunicação de massas e das comunicações difundidas unidirecionalmente e de 'leitura apenas' está a transformar-se na era interativa dos multimédia de 'ler-gravar"” (137).

O futuro dos meios de comunicação social não é totalmente tecnológico nem é um novo humanismo. É uma oportunidade ética de fazer um trabalho magnífico que contribua para uma vida melhor. 
key characteristics of being multimedial, interactive and capable of virtualizing reality. In media life, the world becomes both real and virtual at the same time, as online and offline life spill over, into eachother - a cultural process described by Manuel Castells (2010[1996]) as real virtuality, where the online world of appearances becomes part of everyday lived experience instead of just existing on our computer and television screens. I see it as a social responsibility for media work - and for the students and scholars who study what media professionals and industries do - to be more mindful of the materiality of their work.

\section{Discussion}

In terms of the management and organisation of work, media companies and careers can be considered to quite special, partly because of this delicate and contested balance between the creative autonomy of culture creators, and the instrumental management of commercial enterprises. Zygmunt Bauman (2005) considers the relationship between commerce and culture a sibling rivalry, as “management's plot against the endemic freedom of culture is a perpetual casus belli. On the other hand, culture creators need managers if they wish ... to be seen, heard, and listened to, and to stand a chance of seeing their task/project through to completion" (55).

My argument here, about the future of media as an industry in the context of media life, is that it has a choice to use the contemporary challenges as opportunities to embrace a more critical, ethical and socially responsible role in this world. That said, two key dimensions of media work need to be addressed critically: its precarious labor context, and the need for media users to have access to (and be confronted with) a wide range of content and experiences, especially when it comes to news and information about the world in which they live. As to the first dimension, research is needed into what makes media professionals happy and how the industry can support this happiness - following the thesis that happy workers are more productive and deliver higher quality work (Hesmondhalgh and Baker, 2011; von Rimscha, 2015). With reference to the second dimension, investments in media literarcy and making children mediawise are crucial, insofar such literacy is what John Hartley labels as a multimedia literacy, involving not just critically analyzing media content but also acquiring skills to semi-professionally produce it. As Hartley argues, “the era of one-way 'read-only' media of mass and broadcast communication is transforming into the interactive era of "read-write' multimedia" (137).

The future of media is neither toally technological nor is it a new humanism. It is an ethical opportunity to do beautiful work that contributes to a better life. 


\section{Bibliografia / References}

Balnaves, M., Mayrhofer, D. \& Shoesmith, B. (2004). Media professions and the new humanism. Continuum: Journal of Media and Cultural Studies, 18 (2), 191-203.

Bauman, Z. (2005). Liquid life. Cambridge: Polity.

Bauman, Z. (2007). The consuming life. Cambridge: Polity.

Castells, M. (2007). Power and counter-power in the network society. International Journal of Communication, 1, 238-266.

Castells M. (2010[1996]). The rise of the network society (3rd edition). Cambridge, MA and Oxford: Blackwell.

Cohen, N. S. (2015). Entrepreneurial journalism and the precarious state of media work. South Atlantic Quarterly 114(3), 513-533.

Deuze, M. (2007). Media Work. Cambridge: Polity.

Deuze, M. (2012). Media Life. Cambridge, UK: Polity.

Deuze, M. (2014). Media Life and the Mediatization of the Lifeworld. In A., Hepp, Andreas \& F. Krotz (eds.) Mediatized Worlds: Culture and
Society in a Media Age, , London: Palgrave, 207-220.

Deuze, M. (2016). Living in media and the future of advertising. Journal of Advertising 45(3), 326-333.

van Dijck, J. (2013). 'You have one identity': Performing the self on Facebook and LinkedIn. Media, Culture and Society 35 (2), 199-215.

Hartley, J. (2007). 'There are other ways of being in the truth': The uses of multimedia literacy. International Journal of Cultural Studies 10(1), 135-144.

Hepp, A. (2013). The communicative figurations of mediatized worlds: Mediatization research in times of the 'mediation of everything'. European Journal of Communication 28(6), 615-629.

Hepp, A. \& Friedrick, K. (eds.) (2014). Mediatized Worlds: Culture and Society in a Media Age. London: Palgrave.

Hesmondhalgh D. \& Baker S. (2011). Creative labour: media work in three cultural industries. London: Routledge.

Hjarvard, S. (2012). Doing the right thing: Media and communication studies in a mediatized world. Nordicom Review 33(1), 27-34.
Ihde, D. (1990). Technology and the lifeworld. Bloomington: Indiana University Press.

Jenkins, H. (15 de janeiro de 2003). Transmedia storytelling. Moving characters from books to films to video games can make them stronger and more compelling. Technology Review. http://www.technologyreview.com/biotech/13052.

Jenkins H. (2006). Convergence culture: where old and new media collide. New York: NYU Press.

Lievrouw, Leah, Livingstone, Sonia (eds.) (2004). Handbook of New Media, London: Sage.

Madianou, M. \& Miller, D. (2013). Polymedia: Towards a new theory of digital media in interpersonal communication. International Journal of Cultural Studies 16(2), 169-187.

Meikle, G. \& Young, S. (2012). Media convergence: Networked digital media in everyday life. Basingstoke: Palgrave.

de Mul, Jos (2010). Cyberspace odyssey. Newcastle upon Tyne. Cambridge Scholars Publishing.

von Rimscha, B. (2015). The Impact of Working Conditions and Personality Traits on the Job Satisfaction of 
Media Professionals. Media Indus-

tries Journal 2(2), 1-25.

Scolari, C. A. (2009). Transmedia Storytelling: Implicit Consumers, Narrative Worlds, and Branding in Contemporary Media Production. International Journal of Communication 3, 586-606.

Silverstone, R. (2007). Media and morality: On the rise of the mediapolis. Cambridge: Polity Press.

Sloterdijk, P. (2004). Sphären. Berlin: Suhrkamp. 